\title{
BALTIC TRIPLETS? OUT-MIGRATION MIGRATION AND RESPONSES TO CRISIS
}

\author{
AiJA LULLE ${ }^{1}$ \\ University of Latvia (Latvia)
}

\begin{abstract}
This article addresses intersections of migration and economic development as one of the most topical contemporary challenges in the Baltic states. It uses empirical approach to compare governmental responses to recent economic crisis starting in 2008. Article analyses, how these responses were reflected in statistics revealing socio economic dynamics within years of crisis and beyond. Methods of comparing statistical and analysing secondary data are applied. All three states have similar future challenges of aging and declining population and see return migration as one of possible solutions to address this challenge. However, the processes in Estonia provide a better ground for its government to claim that the country makes effort to ensure more stable development. Also, the results demonstrate that Estonia displays more different trends, while Lithuania and Latvia are closer to each other in outmigration trends.
\end{abstract}

KEYWORDS: Baltic states, migration, crisis, development.

JEL CODES: R100; R230; Y100.

\section{Introduction}

Regions have relative geopolitical locations over time: the Baltic states carry meaning as a part of the Soviet Union and its the furthest margin to the West during the second half of the $20^{\text {th }}$ century, while currently they are the EU member states, a part of 'European space'. In relation to intra-European migration the trio may be seen as the Europe's eastern periphery, supplying migrant labour.

By looking at recent economic developments and migration, this article argues that the Baltic states cannot be treated in a unifying way, due both differences in migration trends and to political and economic dynamics.

On macro level, the general challenge of the Baltic countries, which after the collapse of the Soviet Union adopted open economy approach and have liberal market economies, is similar: all three are experienced large scale emigration and, besides, due to aging and declining population, may face demographic problems in future with subsequent economic effects. Therefore, governments and other institutions in all three countries acknowledge emigration as a serious challenge and try developing policies and taking a stance on return migration as a viable opportunity to address the future problems.

On individual and household level, in Latvia as well as other Baltic states, most important reasons to leave were low salaries, unemployment, personal reasons (Krišjāne et al, 2007; Apsīte-Beriņa, 2013). Many current migrants from the Baltic states, from one hand, state that they may return, if overall situation improves in their countries and, on the other, the state representatives claim that return may be facilitated along

\footnotetext{
Aija Lulle - University of Latvia, Faculty of Geography and Earth Sciences; PhD candidate, geographic mobility and migration studies 
with general economic development (Apsīte-Beriņa, 2013; Lulle, 2011; Hazans, 2009). These above mentioned contexts lay out existing problems in three countries and form basis for the research focus.

The purpose of the article is to show that there are differences within three countries, if we have a closer look to dynamics on yearly basis during crisis. By using comparison of economic dynamics and migration patterns, the goal of this article is to provide data-based explanation show (dis)similar political and economic development trends are in three Baltic states and subsequently, how grounded governmental claims to encourage return migration to successfully recovering countries are?

Methodology and research design are developed with the main goal to provide evidences comparatively. Therefore, the main source of data is Eurostat with its robust methodology on data collection and interpretation. In cases, when these data are not available, they are supplemented by national data and other sources. Secondary sources from existing research on out-migration patterns in the Baltic states are analysed. In following chapters the tasks to achieve the goal are undertaken: (1) to compare recent out-migration trends, (2) to compare political and economic responses to crisis and main indicators of development, as reflected in statistics and (3) derive conclusions.

\section{Out-migration trends in the Baltics}

The first geographer Georg Ravenstein (1885) in his migration laws formulated more than a century ago stated that migration most people move to places where are better wages, predominantly, in close proximity, migration is gender specific, as more men move abroad and further distances, while more women move in shorter distances. Also, he stated that each stream has its counter stream, in other words, return migration also takes place. Situation has changed profoundly since Ravenstein's laws were formulated, especially due to transport connections. However, his basic ideas still suggest valuable ideas to migration research.

According to the Estonian Human Development Report 2011, the collective populations of Estonia, Latvia and Lithuania had dropped by 1.5 million, or $15 \%$, from 1990 to 2010, the fastest decline seen in Europe during that period. For example, Latvian population census shows that the decline in population in 2001-2011 was from 2.3 million to 2 million. Actual population size (according to the recent census in 2011 population size was $2,070,371$ in Latvia, 2,988,000 in Lithuania and 1,294,236 persons in Estonia.

\subsection{Lithuania}

In Lithuania population from 3.67 million in 1990s have decreased to 2.98 million in 2013; in other words about 700 thousand less inhabitants in two decades (Krupickaite 2013, based on Statistics of Lithuania and calculations). Due to natural reasons populationdecreased by 96,46 thousand, and by 618,94 thousand due to net migration in 1990-2013.

The largest Lithuanian diasporas abroad, taking together several waves of outmigration in $20^{\text {th }}$ century are US $(700,000)$, UK $(200,000)$, Ireland $(90,000)$. UK and Ireland clearly form new diasporas of labour migration as well as Nordic countries more recently, though, still smaller in numbers. However, it should be noted, that there was also a large diaspora of Lithuanians in exile in UK (Krupickaite 2013, based on Lithuania Ministry of Foreign Affairs). According to Krupickaite, period of 1995-2003 can be characterised as increasing emigration, while after EU accession in 2004, emigration peaked and continued to grow and those, who were already working, for example, in Ireland and UK, legalised their status. The biggest recent emigration event from Lithuania took place in 2010. Declared emigration from Lithuania increased from 21,970 to 83,160 persons, in relative terms $2.5 \%$ of population, which is exceptionally fast exodus (Krupickaite, 2013). Last economic crisis has profoundly impacted emigration in Lithuania. Most of emigrants are at working age: for example, $77 \%$ of Lithuanian emigrants in 2010 fell in the age group of 15-44 (Lietuvos statistikos departamentas, 2012).

According to estimates in Lithuania, 33,745 or about third of those who emigrated in 2001-2009, returned back to Lithuania (Krupickaite, 2013). Thus, crisis and its aftermath are indeed defining feature in 
Lithuania that could open up a new stage of differentiating emigration, return and stabilisation trends. From the view of government, it is crucial how to ensure this stabilisation and better opportunities for return.

\subsection{Latvia}

During the past decade more than 213 thousands have emigrated and in 2011 Latvia's population was 2070,371 according to Census in 2011, down from 2.3 million counted in 2001 Census. So roughly, $10 \%$ of population, mainly economic active people left Latvia in one decade. Emigration especially peaked after joining the European Union (EU) and in 2009 and 2010 as a response to deep economic recession, which started in late 2008 .

The difference in the level of remuneration was the main driving force and the most frequent motivation of those with secondary/vocational education and low paid jobs in Latvia, who were more likely to be found outside the capital city (Krišjāneet al, 2007). The study also found that international mobility was twice as high among 20-29 year-olds compared to all other respondents, while the majority of respondents intended that their migration be short term. The main destinations for recent migration were the Great Britain and Ireland (Krišjāne, 2011). Since 2011 there is an increasing attractiveness of Nordic countries as well, however, numbers are still low. Internet based survey in 2012 revealed that about $20 \%$ of Latvian citizens living abroad wish to return, while $42 \%$ expressed such wish but were uncertain if the intentions will be actually realised. Besides, those, who emigrated during the crisis, more often stated that they do not intend to return, which indicate distrust to governmental actions and ability to secure more stable future development (Apsīte-Beriņa, 2013). Majority of respondents expressed a will to return, when economic downturn started in Ireland and UK in 2006-2007; however, many could not realise their intentions because they become more settled in these countries and, most importantly, Latvia turned into severe recession in late 2008 (Barcevičiuset al, 2012).

\subsection{Estonia}

According to Census in 2011, population in Estonia was 1.29 million. The decrease of population due to emigration is clearly less than in other two Baltic countries: during years 2000-2008, 29,377 people emigrated from the country. Reiter (2013) states that 25.7 thousands of Estonian citizens were employed abroad in 2012, while 6.2 thousands have emigrated by 2011, the latest available statistical information. Estonian data shows that during economic downturn in 2009-2011 there was no considerable increase in emigration trends and in numbers of those employed abroad. Actually, in 2010-2011, there was even slight decrease from 22.1 to 21.6 thousands employed abroad, which is in sharp contrast with emigration peak in Lithuania and emigration trends in Latvia in 2009-2010. Most emigrants are young; the biggest age group are 25-29 years-old (Tammaru. 2013). According to population register, in total 87.2 thousands of Estonian citizens were living outside Estonian territory (Reiter. 2013). In proportional terms, Estonian citizens, working abroad consist $3.6 \%$ of Estonian labour force and $4.1 \%$ of employed. In Estonian case, considerably more men work abroad, proportionally to Estonia-based labour force, $7.2 \%$ men and $3.5 \%$ women respectively. This could be explained by attraction of Estonian migrants in construction and others male dominated professions in the most attractive destination countries, most notably, neighbouring Finland. $20 \%$ of Estonians were employed in construction abroad in 2012 (Reiter, 2013). Biggest Estonian diasporas abroad are in Finland (about 30 thousands), Sweden (25 thousands) and USA (25 thousands), where the last two comprise also the post-war exile diasporas (Tammaru, 2013; Tammaruet al, 2010). Vast majority - $74 \%$ - of Estonian respondents said, that reason for emigration are low salaries, unemployment and a will to earn better wages (Veidemann, 2010, quoted in Reiter 2013). 
Lastly, return migration takes place also in Estonia, however, no precise data was available. Besides, due to proximity of Finland, Estonia differs from two other countries on more pronounced weekly or similarly frequent commuting trends, where people work abroad but are still considered as living in Estonia.

To sum up, Lithuania and Latvia are more similar in terms of destinations countries of recent migrants, and Lithuania has experienced the biggest population loss due to emigration. Trends in Estonia rather more reflect basic assumptions of Ravenstein's (1885) migration laws due to closer economic cooperation, geographical proximity and cultural closeness to Finland.

\section{Recent political and economic dynamics}

\subsection{Responses to crisis}

Estonia has joined the European monetary union in 2011 but also both other countries are bound to Eurozone through their currencies pegged in euro-area. This was also the reason why countries did not choose devaluation strategy during the crisis. Euro-peg underpins the monetary and fiscal policy, strategy to recover after the crisis. Latvia was the only Baltic state forced to ask EC and IMF support. Financial assistance of 7.5 billion US dollars amounted over $30 \%$ of Latvia's Gross Domestic Product (GDP). A fiscal austerity programme in Latvia was approximately $15 \%$ of GDP between 2008 and 2011.

The size of the measures undertaken to correct the budgets in 2008 and 2009 in all three Baltic states reached 8-7\% of GDP. Wages in public sector were cut by $18 \%$ in 2009 and a further $9 \%$ in 2010 in Latvia and around half of that in Estonia and Lithuania (Kallasteand Woolfson, 2013).

Public sector salaries were cut by $30 \%$ in Latvia and 20-30\% in Lithuania during the crisis. Austerity measures included reductions and reforms of maternity and child allowances and benefits, reductions in unemployment and health insurance. Value added tax (VAT) and excise taxes were increased in all Baltic countries. The increase of VAT in Lithuania was from $18 \%$ to $21 \%$, and in Latvia from $18 \%$ to $22 \%$, and in Estonia from $18 \%$ to $20 \%$. In Latvia corporate income tax was increased from $24 \%$ to $26 \%$ and as well as real estate tax and the non-taxable minimum personal income tax threshold was reduced by almost twothirds in 2009, while personal income tax increased from $24 \%$ to $26 \%$. VAT in Latvia was reduced again to $21 \%$ in July 2012.

In Latvia and Lithuania due to global financial crisis, the governments had to reduce the contributions to second pillar pension funds from 8 to $2 \%$ in Latvia and from $5.5 \%$ to $1.5 \%$ in Lithuania. The reduction of the state contributions to the second pillar in Latvia and Lithuania has meant that future retirees, who participate in the second pillar, will get lower pensions than it was originally planned.

Estonian government had also taken measure to reduce social insurance fund deficit and redirected state contributions from second pillar to first in 2009 and 2010, but returned to $2 \%$ state second pillar contributions in 2011 and to the original $4 \%$ in 2012, with a catch-up period of $6 \%$ state contributions scheduled for 2014-2017 (Aidukaite and Genelyte, 2012).

After the deep crisis, the GDP growth in the Baltic countries is among highest in the EU in past and current years: in 2011 yearly growth of GDP was $8.3 \%$ in Estonia, $5.5 \%$ in Latvia and 5.9\% in Lithuania, while EU27 average was $1.5 \%$ (Eurostat, 2012).

\subsection{Economic dynamics in the Baltic states since 2008}

In the meantime International Monetary Fund (2013) forecasts that the economy is expected to grow at an average rate of $3.2 \%$ in forthcoming years in Latvia. It will take another three years, at least until 2015, before the Latvian economy reaches the 2006-2007 pre-crisis real GDP level. 
Table 1. Real GDP growth (\%)

\begin{tabular}{|l|l|l|l|l|l|l|l|}
\hline $\begin{array}{c}\text { Country/ } \\
\text { year }\end{array}$ & \multicolumn{1}{|c|}{$\mathbf{2 0 0 8}$} & $\mathbf{2 0 0 9}$ & $\mathbf{2 0 1 0}$ & $\mathbf{2 0 1 1}$ & $\mathbf{2 0 1 2}$ & $\mathbf{2 0 1 3} \mathbf{f}$ & $\mathbf{2 0 1 4 \mathbf { f }}$ \\
\hline EE & -4.2 & -14.1 & 3.3 & 8.3 & 3.2 & 3.0 & 4.0 \\
\hline LV & -3.3 & -17.7 & -0.9 & 5.5 & 5.6 & 3.8 & 4.1 \\
\hline LT & 2.9 & -14.8 & 1.5 & 5.9 & 3.7 & 3.1 & 3.6 \\
\hline
\end{tabular}

Source:Eurostat, 2013; GDP indices

Table 2. Public balance, general governmental debt 2008-2011 (\% of GDP)

\begin{tabular}{|l|l|l|l|l|l|l|l|l|}
\hline \multirow{2}{*}{$\begin{array}{c}\text { Country/ } \\
\text { year }\end{array}$} & \multicolumn{4}{|c|}{ Public balance } & \multicolumn{4}{c|}{ General governmental debt } \\
\cline { 2 - 10 } & $\mathbf{2 0 0 8}$ & \multicolumn{1}{|c|}{$\mathbf{2 0 0 9}$} & $\mathbf{2 0 1 0}$ & $\mathbf{2 0 1 1}$ & $\mathbf{2 0 0 8}$ & $\mathbf{2 0 0 9}$ & $\mathbf{2 0 1 0}$ & $\mathbf{2 0 1 1}$ \\
\hline EE & -2.9 & -2.0 & 0.2 & 1.1 & 4.5 & 7.2 & 6.7 & 6.1 \\
\hline LV & -4.2 & -9.8 & -8.1 & -3.4 & 19.8 & 36.7 & 44.5 & 42.2 \\
\hline LT & -3.3 & -9.4 & -7.2 & -5.5 & 15.5 & 29.3 & 37.9 & 38.5 \\
\hline
\end{tabular}

Source: Eurostat, 2012; Public balance and governmental debt

From high inflation rates in 2008, all countries plummeted into very low inflation in 2009-2010and even deflation (Latvia, 2010), while inflation started climbing again in 2011.

Table 3. Annual average inflation rates (\%)

\begin{tabular}{|c|c|c|c|c|}
\hline Country/ year & 2008 & 2009 & 2010 & 2011 \\
\hline $\mathbf{E E}$ & 10.6 & 0.2 & 2.7 & 5.1 \\
\hline $\mathbf{L V}$ & 15.3 & 3.3 & -1.2 & 4.2 \\
\hline LT & 11.1 & 4.2 & 1.2 & 4.1 \\
\hline
\end{tabular}

Source: Eurostat, 2012; inflation indices

There are considerable share of shadow economy in all three states. However, in this measure Latvia stands out against two other Baltic states.

Table 4. Shadow economy index in the Baltic states (\% of GDP)

\begin{tabular}{|l|l|l|l|}
\hline \multicolumn{1}{|c|}{ Country/year } & \multicolumn{1}{c|}{$\mathbf{2 0 0 9}$} & \multicolumn{1}{c|}{$\mathbf{2 0 1 0}$} & \multicolumn{2}{c|}{$\mathbf{2 0 1 1}$} \\
\hline EE & 20.2 & 19.4 & 18.9 \\
\hline LV & 36.6 & 38.1 & 30.2 \\
\hline LT & 17.7 & 18.8 & 17.1 \\
\hline
\end{tabular}

Source:Sauka and Putniņš, 2012

\subsection{Demographic trends: youth and pensioners}

Population is aging in all three Baltic states with similar trends: for example, during a decade 2000-2010 population aged over 65 increased by 338 thousands, from 14.8 to $17.4 \%$, or by 2.6 percentage points in Latvia (CSB, 2012). 
Table 5. Age structure in 2011 (thousands)

\begin{tabular}{|l|l|l|l|}
\hline \multicolumn{1}{|c|}{ Country/ by age group } & \multicolumn{1}{|c|}{$\mathbf{0 - 1 4}$} & $\mathbf{1 5}-\mathbf{6 4}$ & \multicolumn{1}{c|}{$\mathbf{6 5 +}$} \\
\hline EE & 15.1 & 67.2 & 17.7 \\
\hline LV & 13.7 & 68.9 & 17.4 \\
\hline LT & 13.8 & 69.7 & 16.5 \\
\hline
\end{tabular}

Sources: CSB 2012;Lietuvosstatistikosdepartamentas, 2012; Statistics of Estonia, 2012

Overall, the life expectancy, which is one of important indicators of quality of life, is highest in Estonia (76 years, 2010), in Latvia it is 73.7 years, and in Lithuania 73.5 years of average life expectancy.

Since most of out-migrants from the Baltic states are young and taking into account, that return migration might imply needs to improve or add new skills in life-long learning, education is also important indicator to understand dynamics in the Baltic countries.

Table 6. Tertiary level attainment (\%) of population*

\begin{tabular}{|c|c|c|c|c|c|}
\hline Country/ year & 2008 & 2009 & 2010 & 2011 & Target 2020 \\
\hline $\mathbf{E E}$ & 34.1 & 35.9 & 40.0 & 40.3 & 40 \\
\hline LV & 27 & 30.1 & 32.3 & 35.7 & 34 \\
\hline LT & 39.9 & 40.6 & 43.8 & 45.4 & 40 \\
\hline
\end{tabular}

Sources: CEDEFOP, based on Eurostat,2012; EU Labour force survey, 2012

Data shows that Estonia is making considerably bigger effort to involve its inhabitants in life-long learning.

Table 7. Adult participation in Lifelong Learning (\%)*

\begin{tabular}{|l|l|l|l|l|}
\hline \multicolumn{1}{|c|}{ Country/ year } & \multicolumn{1}{|c|}{$\mathbf{2 0 0 8}$} & \multicolumn{1}{c|}{$\mathbf{2 0 0 9}$} & \multicolumn{1}{c|}{$\mathbf{2 0 1 0}$} & \multicolumn{1}{c|}{$\mathbf{2 0 1 1}$} \\
\hline EE & 9.8 & 10.5 & 10.9 & 12 \\
\hline LV & 6.8 & 5.3 & 5 & 5 \\
\hline LT & 4.9 & 4.5 & 4 & 5.9 \\
\hline
\end{tabular}

*(persons aged 25-64, who stated that they received education or training in the four weeks preceding the survey)

Sources: CEDEFOP, based on Eurostat, 2012; EU Labour force survey, 2012

To prevent emigration of young people, countries should address the problem of youth unemployment. Latvia and Lithuania are among the eight EU countries with the highest youth unemployment rates, while situation in Estonia is slightly better.

Table 8. Youth unemployment (age group 15-24)

\begin{tabular}{|l|l|l|l|l|l|l|}
\hline \multirow{2}{*}{ Country } & \multicolumn{3}{|c|}{ Rate } & \multicolumn{3}{c|}{ Ratio } \\
\cline { 2 - 7 } & \multicolumn{1}{|c|}{$\mathbf{2 0 0 9}$} & $\mathbf{2 0 1 0}$ & $\mathbf{2 0 1 1}$ & $\mathbf{2 0 0 9}$ & $\mathbf{2 0 1 0}$ & $\mathbf{2 0 1 1}$ \\
\hline EE & 27.5 & 32.9 & 22.3 & 11.0 & 12.6 & 9.1 \\
\hline LV & 33.6 & 34.5 & 29.1 & 14.0 & 13.9 & 11.2 \\
\hline LT & 29.2 & 35.1 & 32.9 & 8.9 & 10.4 & 9.6 \\
\hline
\end{tabular}

Source: Eurostat, 2012; youth unemployment indices 
As already stated above, population are aging and declining in all three countries. World Social security report 2010/2011(reference year 2009) wage and salaried employment as a share of total employment was slightly lower in Lithuania $88.9 \%$ (92.3\% in Estonia and $89.9 \%$ in Latvia), while proportion of working age population, contributing to old age pension scheme reveal more alarming trends in Lithuania, $56 \%$, while in Estonia it was $68.3 \%$ and in Latvia $66.5 \%$ (WSSR, 2011).

According to national statistical information (reference year 2009), average monthly old-age pension was the highest in Estonia (301 EUR), while in Latvia it was 230 EUR and in Lithuania 233 EUR (Lietuvosstatistikosdepartamentas, 2011; CSB Latvia, 2011; Statistics of Estonia, 2011).

\subsection{Wages, employment and poverty}

Unemployment in years of crisis was skyrocketing, in Lithuania and Latvia in particular. Although, national institutions provide unemployment figures, Eurostat is used here to provide comparison in all three countries. Unemployment rapidly in creased during the crisis: in 2010 official unemployment levels in Latvia and Lithuania were 17-19\% and still reminded among the highest in $3^{\text {rd }}$ quarter of 2012 with more than $15 \%$ in both countries. However, all three states show good recovery in employment rates: compared to 2010, the highest increases of employment rate were recorded in Estonia $4.1 \%$, Lithuania $2.9 \%$, and Latvia $2.5 \%$.

Table 9. Employment rates by age and gender, 2011

\begin{tabular}{|c|c|c|c|c|c|c|c|c|c|}
\hline \multirow{3}{*}{ Country } & \multirow{2}{*}{\multicolumn{3}{|c|}{$\begin{array}{c}\text { Total employment, numbers, } \\
\text { thousands }\end{array}$}} & \multicolumn{6}{|c|}{ Rate \% } \\
\hline & & & & \multicolumn{3}{|c|}{$15-64$} & \multicolumn{3}{|c|}{$55-64$} \\
\hline & Total & Men & Women & Total & Men & Women & Total & Men & Women \\
\hline EE & 609 & 301 & 308 & 65.1 & 67.7 & 62.8 & 57.2 & 57.3 & 57.1 \\
\hline $\mathbf{L V}$ & 971 & 470 & 492 & 61.8 & 62.8 & 60.8 & 51.1 & 52.6 & 49.9 \\
\hline LT & 1371 & 667 & 704 & 60.7 & 60.9 & 60.5 & 50.5 & 54.5 & 47.4 \\
\hline
\end{tabular}

Source: Eurostat, 2012;EU Labour force survey, 2012

All three countries have implemented unemployment insurance that is earnings related, but has minimum and maximum ceilings. To qualify for unemployment benefits in Lithuania a person should be at least 18 months in paid employment, while in Latvia it is at least 9 months, in Estonia - at least for 6 months (Aidukaite and Genelyte, 2012). According to analysis by Aidukaite and Genelyte (2012), Estonia has more favourable situation for unemployed if three Baltic states are compared. The duration for payment of unemployment benefits in Lithuania is up to six months (with work record below 25 years). In Latvia - nine months payment 9work record (one to 19 years). In Estonia - up to 6 months (work record below 4.6 years; up to 9 months if the insurance period is $4.5-9$ years; up to one year if work record is 9 years or more.

Table 10. Unemployment rate (\%) in the Baltic states

\begin{tabular}{|l|l|l|l|l|}
\hline \multicolumn{1}{|c|}{ Country } & \multicolumn{1}{c|}{$\mathbf{2 0 0 8}$} & $\mathbf{2 0 0 9}$ & \multicolumn{1}{c|}{$\mathbf{2 0 1 0}$} & \multicolumn{1}{c|}{$\mathbf{2 0 1 1}$} \\
\hline EE & 5.5 & 13.8 & 16.9 & 12.5 \\
\hline LV & 7.5 & 17.1 & 18.7 & 15.4 \\
\hline LT & 5.8 & 13.7 & 17.8 & 15.4 \\
\hline
\end{tabular}

Source: Eurostat, 2012; Unemployment indices

Real wages grew in 2007 by one fifth in Latvia and 13-14 \% in Lithuania and Estonia. The growth continued also into 2008. But during the crisis in 2009 and 2010 there was a decline of real wages by 5-8 \% in 2009 and 2-6\% in 2010 in all three states. Nominal wages declined in 2009 in all Baltic countries up to $5 \%$ and in 2010 there were still declining in Latvia and Lithuania (Kallaste, Woolfson, 2013). 
Gross monthly minimum wage in Purchasing Parity Power in July 2012, according to Eurostat was as following: 367 in Estonia, 382 in Latvia and 353 in Lithuania.

According to national statistical offices, the average monthly wage was in 2010 in Estonia 792 EUR, Latvia 633 EUR and Lithuania 576 EUR. The average monthly wage grew in Latvia by $4.4 \%$ in 2010.

In regard to the most important criterion by migrants themselves - level of salaries - Estonia was again ahead two other countries, while in Lithuania decrease was reflected in statistics of average salaries during the crisis.

Table 11. Net average monthly salaries*

\begin{tabular}{|l|l|l|l|}
\hline \multicolumn{1}{|c|}{ Country/year } & \multicolumn{1}{|c|}{$\mathbf{2 0 0 8} \mathbf{2 0 0 9}$} & \multicolumn{1}{c|}{$\mathbf{2 0 1 0}$} \\
\hline EE & 557.89 & 529.45 & 536.50 \\
\hline LV & 419.24 & 428.10 & 424.64 \\
\hline LT & 404.41 & 376.90 & 369.92 \\
\hline
\end{tabular}

Source: Eurostat, 2013; *Net salary after taxes and with social allowances calculated as for a single parent without children allowances

If minimum monthly salaries are compared, there was no positive dynamics during and after the crisis in Lithuania. Estonia was doing better in terms of lower proportion of minimum wage earners. According to Eurostat, from the Baltic states only Latvia was among nine EU countries were tax burdens on low wage earners in 2012 was above $40 \%$.

Table 12. Gross minimum monthly salaries (EUR)

\begin{tabular}{|l|l|l|l|l|l|}
\hline \multicolumn{1}{|c|}{ Country/year } & \multicolumn{1}{|c|}{$\mathbf{2 0 0 8}$} & \multicolumn{1}{|c|}{$\mathbf{2 0 0 9}$} & \multicolumn{1}{c|}{$\mathbf{2 0 1 0}$} & \multicolumn{1}{c|}{$\mathbf{2 0 1 1}$} & \multicolumn{1}{c|}{} \\
\hline EE & 278.02 & 278.02 & 278.02 & 278.02 & 290 \\
\hline LV & 229.75 & 254.13 & 253.77 & 281.93 & 285.92 \\
\hline LT & 231.70 & 231.70 & 231.70 & 231.70 & 231.70 \\
\hline
\end{tabular}

Source: Eurostat, 2013; Minimum salaries indices

Table 13. Minimum salaries as a proportion of the mean value of average monthly earnings (\%)

\begin{tabular}{|c|c|c|c|c|}
\hline Country/year & 2008 & 2009 & 2010 & 2011 \\
\hline EE & 34.9 & 36.2 & 35.6 & 33.8 \\
\hline LV & 36.2 & 40.9 & 42.2 & 45.1 \\
\hline LT & 39.6 & 40.5 & 42.0 & 44.1 \\
\hline
\end{tabular}

Source: Eurostat, 2013; Minimum salaries indices

Migration trends described above revealed that there are strong gender factor in outmigration, which can be explained by pull factors in receiving countries in industries. However, in order to understand situation in gender terms, valuable indicator is gender pay gap. This is among the rare indicators, where Estonia was doing worse than two other Baltic countries. In 2009 the highest gender pay gapin EU was in Estoniaabove $30 \%$ whereas in Latvia and Lithuania it stood at $15 \%$. In Estonia the highest gender pay gap was found in industry, energy and construction.

In Latvia and Lithuania, that was influenced also by the highest proportion of female low-wage earners compared to the EU average (more than $30 \%$ in each of these countries. Estonia acknowledges that GPG is a major problem in the country; recommendations have been made to diminish the gap through indirect measures (Anspal et at, 2010). That can be partly explained by higher levels of part-time work by women in 
Estonia.

Table 14. Part-time employment (\% of total employment by gender) in 2011

\begin{tabular}{|c|c|c|c|}
\hline Country & Total & Men & Women \\
\hline EE & 9.3 & 5.0 & 13.5 \\
\hline LV & 8.8 & 7.3 & 10.3 \\
\hline LT & 8.2 & 6.5 & 9.8 \\
\hline
\end{tabular}

Source: Eurostat, 2012; Part-time employment indices

Lastly, in terms of inequality and poverty, again, Estonia is doing better than two other countries. Risk of poverty rate (cut-off point: $60 \%$ of median equalised income after social transfers), in Latvia was $21 \%$, in Lithuania $20 \%$, while in Estonia that was $15.8 \%$ in 2010 (Eurostat).

Table 15. Gini-coefficient on income

\begin{tabular}{|c|c|c|c|c|}
\hline Country & 2008 & 2009 & 2010 & 2011 \\
\hline $\mathbf{E E}$ & 30.9 & 31.4 & 31.3 & 31.9 \\
\hline $\mathbf{L V}$ & 37.7 & 37.4 & 36.1 & 35.2 \\
\hline LT & 34.0 & 35.5 & 36.9 & 32.9 \\
\hline
\end{tabular}

Source: Eurostat, 2012; Gini-coefficient

Gini-coefficient measures inequality in society, suggests that Latvia is the most unequal society among the three Baltic states: in 2011 Gini-coefficient for Latvia was 35.2 \%, Lithuania 32.9\% and Estonia 31.9\%.

\section{Conclusions}

Emigration from Latvia, the same as from Lithuania, increased directly after the beginning of the crisis in 2008, while in Estonia there was no sharp increase observed. Therefore, when comparing development trends and out-migration processes during crisis, Estonia displays dissimilar trends to two other Baltic states.

In Estonia's case, the largest diaspora of recent migrants are developing in Finland, which is in close geographical and cultural proximity, while in cases of Lithuania and Latvia the largest new labour diasporas are forming in UK, Ireland and only recently started developing in Nordic countries. These diasporic connections may play an important role in development of countries economically, socially and culturally and develop in even more different trends.

Economic and financial crisis, which started in late 2008 had the profound influence on the Baltic states' economies. Latvia was hit the hardest among the three countries as it was also forced to seek for the international financial help from IMF and the European Commission. However, out-migration form Lithuania was even more significant.

Although, all three states are similar, Estonia has better development trends and economic achievements. Austerity measures on child allowances and contribution to pension funds were milder and temporary as well as recovery from unemployment during the crisis was faster in Estonia. Moreover, there are less low salary earners in Estonia and comparatively less risk of poverty and inequality, compared to Latvia and Lithuania.

To conclude, despite political and historical similarities, both terms of out- migration and responses during the crisis and recovery, the Baltic States display differences, that can lead to further reaching conse- 
quences in future.

\section{References}

Aidukaite, J., Genelyte, I. (2012). Social policy and Migration in the Baltic States. Paper presented at the Annual RC 19 Conference "Welfare States Facing Global Turbulence, Ageing and Migration. Rising to the Occasion, Coping or Adjusting Downwards?", 23-25 August, 2012, Oslo, Norway.

Aidukaite, J. (2011). Welfare Reforms and Socio-economic Trends in the Ten New EU Member States of Central and Eastern Europe. Journal of Communist and Post-Communist Studies, Vol. 44, No. 3, p. 211-219.

Anspal, S., Kallaste, E., Karu, M. (2010). SoolinepalgalõheEestis: poliitikameetmete analüüs. Uuringuraport. Eesti Rakendusuuringute Keskus Cent AR, Poliitikauuringute Keskus PRAXIS, Sotsiaalministeerium. Available: http:// www.sm.ee/fileadmin/meedia/Dokumendid/V2ljaanded/Publikatsioonid/2011/Gender_pay_gap_Estonia_recommendations.pdf

Apsìte-Berina, E. (2013). International migration in the European Union: Migration from Latvia to the United Kingdom. $\mathrm{PhD}$ diss. University of Latvia.

Barcevičius, E., Iglicka, K., Repečkaitė, D., Žvalionytė, D. (2012). Labour Mobility within the EU: The Impact of Return Migration. Eurofund. Available: http://www.eurofound.europa.eu/pubdocs/2012/43/en/2/EF1243EN.pdf

CEDEFOP. (2012). European centre for development and vocational training. Available: http://www.cedefop.europa. eu/EN/Index.aspx

CSB. (2012). Central Statistical bureau, Republic of Latvia. Available: www.csb.lv

EU Labour force survey. (2012). Available: http://epp.eurostat.ec.europa.eu/portal/page/portal/microdata/lfs

Eurostat. (2012; 2013). Available: http://epp.eurostat.ec.europa.eu

$I M F$. (2013). International Monitory Fund and Latvia. IMF Staff Visit to LatviaMay 7-13, 2013 - Concluding Statement. Available: http://www.imf.org/external/country/lva/

Hazans, M. (2009). The Post-Enlargement Migration Experience in the Baltic Labor Markets. In: M. Kahanec, K. F. Zimmermann (eds.). EU Labor Markets after Post-Enlargement Migration. Berlin - Heidelberg: Springer, p. $255-304$.

Kallaste, E., Woolfson, C. (2013). Negotiated Responses to the Crisis in the Baltic Countries. TRANSFER: European Review of Labour and Research, Vol. 19, No. 2, p. 253-266.

Krišjāne, Z. (ed.) (2007). Geographic Mobility of Labour Force. Ministry of Welfare, labour market research. University of Latvia. European Social Fund.

Krišjāne, Z. (2011). Emigrācija - Latvijas jaunāiezīme Goethe Institut. Riga. Available: http://www.goethe.de/ins/lv/ rig/ges/eur/mui/lv7543515.htm

Krupickaite, D. (2013). Destination Change of Emigration from Lithuania. Presented at the Norden conference Migration and Demographic Challenges, Tallinn, 7-8 March, 2013. Available: http://www.norden.ee/images/regionaal/ info/migra/Dovile_Krupickaite_78MarchTallinn.pdf

Lietuvos statistikos departamentas. (2012). Available: http://www.stat.gov.lt/

Lulle, A. (2011). Internal Dynamics of Recent Migration: the Case Study of Latvians in Guernsey. In: T. Muravska, R. Petrov, B. Sloka, J. Vaivads (eds.). European Integration and Baltic Sea Region: Diversity and Perspectives. The University of Latvia Press.

Ravenstein, E. G. (1885). The Laws of Migration. Journal of the Statistical Society, Vol. XLVIII, p. 167-235.

Reiter, L. (2013). Labour Migration from Estonia in Recent Years. Presented at the Norden conference Migration and Demographic Challenges. Tallinn, 7-8 March, 2013. Available: http://www.norden.ee/images/regionaal/info/migra/ Liis_Reiter_78MarchTallinn.pdf

Statistics Estonia. (2012). Available: http://www.stat.ee/statistics

Tammaru, T. (2013). Waves of outward migration from Estonia. Presented at the Norden conference Migration and Demographic Challenges. Tallinn, 7-8 March, 2013. Available: http://www.norden.ee/images/regionaal/info/migra/ Tiit Tammaru 78MarchTallinn.pdf

Tammaru, T., Kumer-Haukanõmm, K., Anniste, K. (2010). The Formation and Development of the Estonian Diaspora. Journal of Ethnic and Migration Studies, Vol. 36, No. 7, p. 1157-1174.

Sauka, A., Putninšš, T. (2012). Shadow Economy Index. Stockholm School of Economics, Riga.

Veidemann, B. (2010). Migration Potential of Working-age Population in Estonia in 2010. Ministry of Social Affairs of Estonia, Labour Policy Information and Analysis Department.

WSSR. (2011). World Social security report 2010/2011. Available: http://www.ilo.org/global/publications/ilo-bookstore/order online/books/WCMS_146566/lang--en/index.htm 


\section{BALTIJOS TRYNUKAI? EMIGRACIJA, MIGRACIJA IR ATSAKAS KRIZE I}

AiJA LULLe

Latvijos universitetas (Latvija)

\section{Santrauka}

Šiame straipsnyje nagrinejjama migracijos ir ekonominio vystymosi sankirta, kaip viena aktualiausiu problemų, su kuriomis susiduria Baltijos šalys. Pasinaudojus empirine prieiga, lyginami vyriausybių veiksmai esant ekonominei 2008 metų krizei. Straipsnyje analizuojama, kaip jie išryškejjo socioekonominę dinamiką atskleidžiančioje statistikoje. Tyrime taikomi lyginamosios statistikos ir antrinių duomenų analizės metodai. Visos trys valstybės patiria panašių ateities iššūkių: visuomenès senėjimas ir gyventojų skaičiaus mažejimas, tuo tarpu emigrantų sugrižimas matomas kaip viena iš priemonių, galinčiu padèti šias problemas spręsti. Estijoje vykstantys procesai leidžia manyti, kad jos Vyriausybei labiau sekasi užtikrinti stabilu vystymąsi, tyrimo rezultatai taip pat rodo, kad Estijoje pastebimos skirtingos tendencijos, tuo tarpu Latvijoje ir Lietuvoje jos panašios tuo, kad čia vyrauja emigracijos tendencija.

PAGRINDINIAI ŽODŽIAI: Baltijos šalys, migracija, krize, vystymasis.

JEL KLASIFIKACIJA: R100; R230; Y100 